\title{
CSERMELY PÉTER
}

\section{Információrobbanás és kollektív intellektus}

\author{
HOZZÁSZÓLÁS PIERRE LÉVY „AZ ÉRTELMISÉG ÚJ FELELŐSSÉGE \\ A KOMMUNIKÁCIÓ KORÁBAN” CÍMÜ ÍRÁSÁHOZ
}

\section{Szerzői információ:}

\section{Csermely Péter}

A Semmelweis Egyetem Orvosi Vegytani, Molekuláris Biológiai és Pathobiokémiai Intézetének professzora. Kutatásai fóként a stresszfehérjék múködésére és a hálózatokra irányulnak. Eddig 11 könyve (köztük a Stresszfeliérjék és a Rejtett hálózatok ereje) és több mint kétszáz, számos szaklapban idézett és hivatkozott tudományos cikke jelent meg. 1995 óta eredményesen szorgalmazza a tehetséges a hazai és határon túli középiskolás diákok bekapcsolódását a Magyarországon folyó legmagasabb szintú kutatásokba. 2006-ban megalakította a magyar tehetséggondozó civil szervezeteket összefogó Nemzeti Tehetségsegítő Tanácsot, amelynek elnökévé választōtták. A Magyar Biokémiai Egyesület alelnöke és a Cell Stress Society International volt elnöke. Munkásságát több hazai és nemzetközi kitüntetéssel, köztük az EU Descartes-díjával ismerték el.

E-mail: csermely@puskin.sote.hu

Így hivatkozzon erre a cikkre:

Csermely Péter. „Információrobbanás és kollektív intellektus”.

Információs Társadalom VIII, 4. szám (2008): 21-23.

— https://dx.doi.org/10.22503/inftars.VIII.2008.4.5

A folyóiratban közölt müvek

a Creative Commons Nevezd meg! - Ne add el! - Így add tovább! 4.0

Nemzetközi Licenc feltételeinek megfelelően használhatók. 
Csermely Péter

\section{Információrobbanás és kollektív intellektus - és ezek jelentósége hazánkban}

Pierre Lévy „Az értelmiség új felelôssége a kommunikáció korában” címú írásához négy gondolatot szeretnék hozzátenni. Ezek közül az első az információrobbanással kapcsolatos. Az emberiség a 20. század utolsó évtizedeitôl kezdve - különösen az internetnek köszönhetốen - a könnyen elérhetố információ mennyiségének robbanásszerú növekedését éli meg. Különösen igaz ez szúkebben vett tudományterületemre, az élettudományokra és ezen belül az orvostudományokra. A rendelkezésre álló és a megalapozott döntésekhez szükséges információ kezelésére az emberi agy logikusan gondolkodó bal féltekéjének kognitív kapacitása (amely az átlagos, nem zseniális urak esetében 4-6, a hölgyek esetében ennél valamivel több, 5-8 információ párhuzamos észben tartását és értékelését teszi lehetốvé) igencsak elégtelen. Hogyan lehet ezen a helyzeten javítani? Információfeldolgozó kapacitásunk bővítésének első lépcsőfoka a képekben gondolkodó, mintázatokat képző, integratív jobb agyfélteke bekapcsolása. Az információkat helyesen összegzố képek minimum két nagyságrenddel tolják ki a párhuzamosan kezelhetố információelemek körét. Néhány száz információ azonban nagyon sok esetben a döntésekhez még mindig kevés. Mit lehet tenni ezen esetekben? Az érzelmeket kell segítségül hívni. Az agy információfeldolgozásának döntô része a tudatalatti régiókban zajlik, és onnan az összegzett eredményt érzelmek formájában küldi fel a tudatos szintre úgy, hogy bizonyos döntési alternatívák ,zsigerileg”vagyis a logikus bal agyfélteke által megmagyarázhatatlanul - pozitívnak, mások pedig negatívnak túnnek. Bármelyikünk, aki kicsit is kommunikatív viszonyban van a saját tudatalatti szférájával, és nem fojtja el az onnan érkezô üzeneteket, hány és hány órát töltött már el életében azzal, hogy az érzelmileg már az első pillanatban teljesen nyilvánvaló döntéseket megpróbálta maga és mások eloótt logikus okokkal is megmagyarázni?

Mi következik a fentiekból? - Nem véletlen, hogy a képi ábrázolás ennyire teret nyert az elmúlt száz évben, és az sem véletlen, hogy az eligazodást adó érzelmi hátteret a kommunikátorok sok esetben a tudat alatti szúrófolyamatok kikapcsolásával és megkerülésével akarják megteremteni. Az egymást követő generációk tehát nem „elbutulnak" vagy manipulálhatók, amikor olvasás helyett a televíziót bámulják, vagy kritikátlan vevók pár szavas, érzelmileg manipulált üzenetekre. A jelszóvilág, a „kövess engem" birkaszelleme az információrobbanás velejárója, és az agykapacitásunk elégtelenségéból fakadó késleltetett választ tükrözi csupán. Hogyan lehet ezt meghaladni? Kellő és okos információszúró mechanizmusok beépítésével, ahol a gazda szúr, és nem helyette szúrnek mások, ốt orwelli sötétségében tartva. Az ezzel párhuzamos másik út a képi, integratív gondolkodás erősítése és a tudatalatti tudatosításának gyakorlása már kicsiny gyermekkorban, amikor ezeket még nem nyomja el a logikus bal agyfélteke és az azt dresszírozó egész nyugati-civilizációs oktatási gyakorlat. 
A második megjegyzésem a tudomány Lévy által jogosan említett és ostorozott feldaraboltságának és az információfeldolgozásnak az összefüggéseit érinti. Napjainkra egyre több olyan információfeldolgozási rendszer alakult ki (ezek közül hadd említsem példaként kedvenceimet, a kutatási területemet képező hálózatokat, lásd www.linkgroup.hu), amelyek tudományterülettól független, univerzális kezelóeszközt biztosítanak az egymástól látszólag független információhalmazok lényegének megtalálására. Az elmúlt tíz év nagyon nagy meglepetése ezen információfeldolgozó rendszerek használata során az volt, hogy vannak olyan univerzális rendezố elvek (például a bonyolult rendszerek elemeinek rövid utakkal való, „súrú” összekötöttsége, ami a „kis világ” jelenségként ismeretes, avagy a rendszerek elemeinek csoportokba tömörülése, ami igen jó információszúrố mechanizmus stb.), amelyek fố vonalaikban a világon fellelhetố összes komplex rendszerre egyformán érvényesek. Így lehetốvé vált egy olyan kutatási séma mind gyakoribb alkalmazása, amely az egyik tudományterületen felismert összefüggést alkalmazza más és más tudományterületeken, és ezzel újraszüli az emberi gondolkodásnak és világképnek a felvilágosodás óta éppen a tudományos gondolkodás térhódítása és a tudomány egyre nagyobb fragmentálódása miatt folyamatosan elveszó egységét. Ennek a folyamatnak jelenleg még csupán a legelejénél vagyunk.

A harmadik megjegyzésem a kollektív intellektushoz kapcsolódik. Napjainkban a kollektív intellektus fogyasztói oldala (pl. az internetról magunkba szívható információtömeg) dominál, és szinte alig ismertük fel ugyanannak a kollektív intellektusnak az alkotói oldalában rejlố elképesztốen nagy lehetôségeit. A virtuális térben való virtuális találkozások és az ebból fakadó (pl. wikipédia-szerú) közös alkotások csak a kezdeti bátortalan lépések ebben. A virtuális térben létrejövố valós együttmúködések nagyon fontos választ jelentenek a fenntarthatóság égetô kérdéskörére is. Ma már az együttes lét, a konferenciák, a megbeszélések kedvéért kontinenseket átszelő repülőutak zöme feleslegessé vált, és igen könnyen helyettesíthetố a virtuális 3D jelenléttel és közös alkotással.

A negyedik és utolsó megjegyzésem az elsô három megjegyzés hazai, magyarországi alkalmazásával kapcsolatos. Magyarország jelenlegi fejlődésére a 21. század elején a valódi kreatív, alkotó tevékenység rendkívül kis aránya és a másutt született kreatív alkotó tevékenység alkalmazását segítô mechanizmusok elképesztố túltengése a jellemzô. Ebben az országban jelenleg minden alkotó értelmiségire (sarkított fogalmazásban) száz kommunikátor, másik száz logisztikai menedzser, újabb száz ún. human resource assistant, még száz vezetéselméleti szaktanácsadó és több száz ügyvéd jut. (Elnézést kérek az érintett szakmákban valódi kreatív és alkotó tevékenységet folytató kisebbségtól.) Az originalitást elnyomja, elnyomta a másolás, ami akkor is lényegileg másolás marad, ha adaptálásnak nevezzük. Túllendült az inga. A rendszerváltás után a világ áramlataiba való újracsatlakozásunk rendkívül fontos és értékes befogadó attitúdje annyira elhatalmasodott, annyira szokássá vált, hogy kiölte az öntudatot és az új, mások által adaptálható alkotó gondolat keresésének merészségét. Ezzel a „leosztással” nem jutunk előre sem az egyre fogyó energiáért, vízért, jó levegőért és nem utolsósorban a tehetségekért kiélesedố világversenyben, sem az EU-n belül és az EU-hoz csatlakozni vágyók körében a periféria felzárkózási sorrendjéért folyó öldökló harcban. Ezzel szemben önnön energiáinkat a kevéske valóban új érték ezer meg ezer, igen sok esetben parazita „lesápolásával”, „lenyúlásával”, „részesedéskérésével” lecsapolva végleg veszí- 
teni fogunk. Az alkotók és az alkotás hasznából részt kérôk arányát - döntően a másutt békés évszázadok alatt kialakult termelési kultúrák hiánya miatt - csak a kiugróan új területeken nyújtott extra erófeszítésekkel lehetünk képesek megváltoztatni. Pontosan e területek egyike az információfeldolgozásnak az elsố három megjegyzésemben érintett új világa. Meg kellene ezt hódítanunk. A magyar matematika sok-sok generációra visszanyúló, kivételesen magas szintú hagyományai, az informatika mai, nav-n-go-féle sikertörténetei igen jó alapot adnak ehhez. Csak az összefogás hiányzik. (Ebben is.) 